\title{
Mortality associated with use of weapons in armed conflicts, wartime atrocities, and civilian mass shootings: literature review
}

\author{
Robin M Coupland, David R Meddings
}

\begin{abstract}
Objective To determine the implications of variation in mortality associated with use of weapons in different contexts.

Design Literature review.

Settings Armed conflicts and civilian mass shootings, 1929-96.

Main outcome measure Mortality from wounds.

Results During the fighting of war the number of people wounded is at least twice the number killed and may be 13 times as high; this ratio of the number wounded to the number killed results from the impact of a weapon system on human beings in the particular context of war. When firearms are used against people who are immobilised, in a confined space, or unable to defend themselves the wounded to killed ratio has been lower than 1 or even 0 .

Conclusions Mortality from firearms depends not only on the technology of the weapon or its ammunition but also on the context in which it is used. The increased mortality resulting from the use of firearms in situations other than war requires a complex interaction of factors explicable in terms of wound ballistics and the psychology of the user. Understanding these factors has implications for recognition of war crimes. In addition, the lethality of conventional weapons may be increased if combatants are disabled by the new non-lethal weapons beforehand; this possibility requires careful legal examination within the framework of the Geneva Conventions.
\end{abstract}

\section{Introduction}

The effects of weapons on humans resulting from their design are different from those resulting from the context in which the weapons are used. The mortality associated with a particular kind of weapon - that is, the proportion of those injured who die-is a measurable outcome. Conventional weapons are designed to cause injury by transmitting kinetic energy to the body, generally not to a specific part of the body (with the exception of buried antipersonnel mines), and arms and legs make up almost half of the human target. ${ }^{1}$ In this article conventional weapons are legitimate weapons currently used by armies that utilise projectiles or non-nuclear explosions. ${ }^{1}$ Little attention has been paid to the fact that the mortality associated with a given weapon varies considerably according to the context in which it is used.

Mortality associated with weapons during war has been recorded in the medical literature. ${ }^{2-13}$ However, weapons might be used in armed conflict but outside the international laws of war-for example, against civilians or to execute prisoners. Weapons have been used by military staff on unarmed civilians or prisoners of war; in such cases the number of dead may be known from a body count or from forensic evidence of mass graves, but the number of survivors is either unknown or likely to be none. ${ }^{14-17}$ Conventional weapons may also be used in urban violence, murders, or terrorism. Firearms, particularly automatic weapons, have been used in mass shootings, in which the number of people killed may be more than the number wounded. ${ }^{18-25}$

We reviewed official figures in the medical literature on mortality from the use of conventional weapons and firearms under various circumstances to see how mortality varies according to the context in which weapons are used.

\section{Methods}

We sought data on the number of people wounded and killed in armed conflicts or mass shootings from three sources: Medline searches; official military casualty figures quoted in the medical literature; and $\mathrm{BBC}$ radio's World Service.

We performed a search on Medline for reports that gave statistics on those wounded and killed in armed conflicts since 1940 . We also wrote to the chief military medical officers of 89 countries as listed in the International Committee of Military Medicine asking for medical publications in Index Medicus that might contain official statistics on casualties; we did not ask for any confidential information.

We performed a search on Medline for reports published since 1980 that reported mass casualties of firearms outside the context of armed conflict, gave the number of people wounded and killed, and gave the context in which the weapons were used in each event. Some of these publications contained data on incidents that happened earlier this century.

In this study wounded means the number of people who were injured and survived to leave hospital, while killed means the number of people whose injuries were fatal, including those killed where the weapons were used (the military equivalent being killed in action) and those who died after reaching a medical facility (the military equivalent being died of wounds). We calculated the ratio of the number of people wounded to the number of people killed.

One of us (RC) tabulated a parallel analysis of some incidents reported on BBC radio's World Service from January 1996 to the end of 1998. These incidents were unverified and do not represent all incidents reported by this news service.

\section{Results}

Table 1 shows the incident or official figures for wounds sustained in the context of armed conflict since 1940 . The ratio of the number of people wounded to the

\author{
Unit of the Chief \\ Medical Officer, \\ International \\ Committee of the \\ Red Cross, \\ 19 avenue de la \\ Paix, 1202 Geneva, \\ Switzerland \\ Robin M Coupland \\ surgeon \\ David R Meddings \\ epidemiologist \\ Correspondence to: \\ R Coupland \\ rcoupland@icrc.org
}

BMJ 1999;319:407-10 
Table 1 Numbers of people wounded and killed by conventional weapons in conflicts during or after second world war as reported in medical literature

\begin{tabular}{|c|c|c|c|c|}
\hline Source & Year & Wounded & Killed & $\begin{array}{l}\text { Wounded to } \\
\text { killed ratio }\end{array}$ \\
\hline \multicolumn{5}{|l|}{ United States } \\
\hline$\overline{\text { Second world war (Italy) }}{ }^{2}$ & $1944-5$ & 76351 & 27953 & 2.7 \\
\hline Vietnam (Marine Corps) $^{3}$ & 1964-73 & 51399 & 12944 & 4.0 \\
\hline Panama $^{4}$ & 1989 & 325 & 25 & 13.0 \\
\hline Mogadishu raid ${ }^{3}$ & 1993 & 70 & 18 & 3.9 \\
\hline \multicolumn{5}{|l|}{ United Kingdom } \\
\hline Malaya (rifles) $)^{5}$ & $1952-3$ & 388 & 204 & 1.9 \\
\hline Northern Ireland (British army) ${ }^{6}$ & $1970-80$ & 1700 & 300 & 5.7 \\
\hline Low velocity bullets & & 362 & 13 & 27.8 \\
\hline High velocity bullets & & 169 & 75 & 2.2 \\
\hline Northern Ireland (explosions only) $)^{7}$ & $1970-84$ & 612 & 216 & 2.8 \\
\hline \multicolumn{5}{|l|}{ Israel } \\
\hline Lebanon $^{8}$ & 1982 & 1599 & 351 & 4.5 \\
\hline \multicolumn{5}{|l|}{ Croatia } \\
\hline Former Yugoslavia ${ }^{9}$ & $1991-2$ & 78 & 15 & 5.2 \\
\hline
\end{tabular}

Table 2 Numbers of people wounded and killed in civilian mass shootings as reported in medical literature

\begin{tabular}{lcrrc} 
Mass shooting & Year & Wounded & Killed & $\begin{array}{c}\text { Wounded to } \\
\text { killed ratio }\end{array}$ \\
\hline St Valentine's Day massacre & 23 & 1 & 6 & 0.17 \\
\hline Katyn Forest massacre $^{14}$ & 1929 & 0 & 4143 & 0 \\
\hline Houston $^{25}$ & 1940 & 44 & 14 & 3.14 \\
\hline Wah Mee massacre $^{25}$ & 1963 & 0 & 13 & 0 \\
\hline San Diego McDonald's & 19 & 11 & 21 & 0.52 \\
\hline Palm Bay $^{21}$ & 1983 & 14 & 6 & 2.33 \\
\hline Melbourne $^{19}$ & 1984 & 19 & 7 & 2.71 \\
\hline Melbourne $^{19}$ & 1987 & 5 & 9 & 0.55 \\
\hline Hungerford $^{18}$ & 1987 & 13 & 17 & 0.76 \\
\hline Sydney $^{19}$ & 1987 & 0 & 7 & 0 \\
\hline Killeen massacre $^{22}$ & 1987 & 19 & 24 & 1.67 \\
\hline Fairchild $^{20}$ & 1991 & 1991 & 5 & 4.4 \\
\hline Case report $^{24}$ & 1991 & 1 & 3 & 0.33 \\
\hline
\end{tabular}

Table 3 Numbers of people wounded and killed in incomplete and unverified selection of military or paramilitary incidents from January 1996 to end of 1998, as reported by BBC radio's World Service

\begin{tabular}{|c|c|c|c|}
\hline Incident & Wounded & Killed & $\begin{array}{l}\text { Wounded to } \\
\text { killed ratio }\end{array}$ \\
\hline \multicolumn{4}{|l|}{1996} \\
\hline Mogadishu (fighting) & 400 & 100 & 4.0 \\
\hline Israel/Lebanon (bombing) & 400 & 100 & 4.0 \\
\hline Saudi Arabia (US Airbase bomb) & 160 & 19 & 8.4 \\
\hline Jakarta (fighting/riots) & 90 & 2 & 45.0 \\
\hline Sri Lanka (shelling/bombing) & 100 & 30 & 3.3 \\
\hline Kashmir (grenade incident) & 20 & 1 & 20.0 \\
\hline Israel/Palestine (fighting) & 435 & 55 & 7.9 \\
\hline Nouth Korean submarine (fighting) & 0 & 21 & 0 \\
\hline Copenhagen (antitank missile) & 17 & 2 & 8.5 \\
\hline \multicolumn{4}{|l|}{1997} \\
\hline Tel Aviv (bomb) & 30 & 4 & 7.5 \\
\hline Sri Lanka (fighting, Tamil casualties) & 70 & 80 & 0.87 \\
\hline Peru (raid on Japanese embassy) & 0 & 14 & 0 \\
\hline Karachi (fighting/riot control) & 22 & 2 & 11.0 \\
\hline \multicolumn{4}{|l|}{1998} \\
\hline Uganda (fighting) & 12 & 4 & 3.0 \\
\hline Freetown (airstrike) & 28 & 4 & 7.0 \\
\hline Sri Lanka (fighting, government casualties) & 200 & 35 & 5.7 \\
\hline
\end{tabular}

number killed ranged from 1.9 to 27.8 . Two additional articles gave the proportions of people wounded who eventually died in major conflicts since 1940, without giving absolute numbers. ${ }^{10}{ }^{11}$ Total deaths were never more than $26 \%$ of all casualties, a wounded to killed ratio of 2.8. In two reports accurate casualty figures were known for soldiers wounded by rifles in a military context. ${ }^{56}$ The wounded to killed ratios were 1.9 and 2.2 .

Table 2 shows the incidents in which weapons, mostly automatic military rifles, were used outside armed conflict. The wounded to killed ratio ranged from 0 to 4.4. Comparison of the data in tables 1 and 2 showed that in the context of armed conflict the number of people killed was never more than the number of people wounded and the wounded to killed ratio did not fall below 1.9. By contrast, in a context outside armed conflict the use of military firearms frequently resulted in more people dying than being wounded.

Table 3 shows the absolute numbers of people wounded and killed and the wounded to killed ratio for an incomplete list of some military or paramilitary operations reported by BBC radio's World Service.

\section{Discussion}

Mortality from firearms differs with the context in which they are used. This might not need substantiation, but understanding this relation might allow data on mortality to determine the context in which weapons were used. This has important implications for the recognition of war crimes.

\section{Limitations of the study}

This study has several limitations. The medical literature does not contain statistics on all battles or civilian incidents in which firearms have been used. However, the articles we found include large numbers from different situations.

Military casualty figures come only from armies with a good medical infrastructure. No figures could be found for the armies currently fighting wars in developing countries; their wounded are unlikely to benefit from recent developments in care of casualties which increase the proportion of wounded people who survive. However, even without modern medical care the number killed is less than the number wounded. ${ }^{30-13}$ The lack of medical infrastructure is unlikely to cause the wounded to killed ratio to vary from the values in table 1 .

A further consideration is whether the mortality associated with wounds from assault rifles can be compared with the mortality from all conventional weapons. Only two military publications provide separate data on mortality from bullet wounds. ${ }^{56}$ These and other studies show how similar the data on size of wound and mortality are for bullets and explosions and fragmentation munitions. ${ }^{171226}$ Therefore, the wounded to killed ratios for all conventional weapons are comparable. Firing by snipers alone may generate a low ratio.

\section{Mortality in context}

If mortality associated with use of firearms varies according to context, the higher mortality associated with some of the incidents in table 2 can be partly explained by wound ballistics. Firstly, the victims are likely to be closer to the user, and so the kinetic energy available for deposit in the body is greater, which in 
turn results in larger wounds. ${ }^{27}{ }^{28}$ Secondly, victims are more likely to have multiple wounds from automatic rifles. Thirdly, firing automatic rifles at close range increases the chance of fatal injury. In addition, users close to their victims may decide to direct the weapon at the head or central chest. The fundamental importance of this psychology as a factor in, for instance, the My Lai massacre has been examined in depth. ${ }^{29}$

In the mass shootings in which the wounded to killed ratio was less than 1 the civilians were unarmed or could not take cover. The implication of this is that when the victims are military, an equally low wounded to killed ratio could be a strong indicator of death by execution rather than in battle. This would provide a tool for states, lawyers, agencies, and journalists who monitor or investigate compliance with the laws of war. For example, 500 soldiers missing after an opposing army has overrun a town are unlikely to have been killed in battle-as the victors might claim-if only 20 of their number are wounded in the local hospital. Similarly, if an official news report states that a certain number of terrorists were killed in a gun battle without any survivors, those wounded or captured are likely to have been executed. Wounded combatants are protected by the first Geneva Convention and prisoners of war by the third.

Mass shootings with weapons in a military, paramilitary, or civilian context generate considerable media interest. The numbers killed are known with more certainty than the numbers wounded and are therefore usually given because a body count is easier than finding and counting wounded people in different hospitals. Two mass shootings in which the number of wounded and killed were accurately recorded occurred in Dunblane in 1996 (17 people died and 12 were injured) and Port Arthur in 1996 (34 people were killed and 18 reached hospital); each was carried out by one man. The wounded to killed ratios are 0.7 and 0.5 respectively, and this is further evidence that the number of people killed can be greater than the number of wounded in civilian contexts. In a military or paramilitary context, however, the media rarely comment when the number of killed surpasses the number of wounded.

Understanding how and why the wounded to killed ratio falls below 1 should lower the threshold of suspicion and provide evidence of war crimes. The data on the unverified incidents in table 3 could be reviewed with this in mind.

\section{"Non-lethal" weapons}

The principle that mortality or lethality may be determined not only by a weapon's technology but also by how it is used is crucial to the debate about new or "non-lethal" weapons. These new weapon technologies are intended to give the commander the ability to conduct warfare with minimal deaths and injury. The antipersonnel component of this new technology is designed to cause incapacitation; it includes sticky foam, calmative agents, and energy sources such as infrasound and electromagnetic waves. ${ }^{30-36}$

However, even proponents of "non-lethal" weapons acknowledge that no weapon can be used without causing some deaths. Furthermore, they acknowledge that these weapons will always be backed up by
Key messages

- Mortality from firearms varies according to the context in which they are used

- In war the number of people wounded is at least twice the number killed

- The number killed may be greater than the number wounded when firearms are used against people who are immobilised, in a confined space, or unable to defend themselves

- Recognising how the wounded to killed ratio varies has implications for recognising war crimes

- Combining use of weapons that are designed to incapacitate with use of conventional weapons requires examination under the law of war

conventional weapons. ${ }^{30}$ This raises the spectre of people who are hors de combat-that is, unable to use their weapons or to take cover-being exposed to the effects of conventional weapons. Given the increased mortality in some of the incidents reported in table 2, the concern that "non-lethal" weapons could, paradoxically, lead to a higher mortality from conventional weapons is well founded. ${ }^{32}$ Combining the effects of these two weapon systems in war must be examined from the legal perspective.

Contributors: RMC formulated the original idea for the study and undertook the literature review. DRM designed the study. Both wrote the paper. RMC is guarantor.

Funding: No additional funding.

Competing interests: None declared.

1 Coupland RM, ed. The SIrUS Project:towards a determination of which weapons cause "superfluous injury or unnecessary suffering." Geneva: Internationa Committee of the Red Cross, 1997.

2 Reister FA. Medical statistics in world war II. Washington, DC: Department of the Army, Office of the Surgeon General, 1975:76-9.

3 Bellamy RF. Combat trauma overview. In: Zaitchuk R, Grande CM eds. Anesthesia and perioperative care of the combat casualty. Falls Church, VI: Office of the Surgeon General, United States Army, 1996.

4 Dice WH. The role of military emergency physicians in an assault operation in Panama. Ann Emerg Med 1991;20:1336-40.

5 Clyne AJ. The wounding and killing power of small-arms fire in jungle operations. J R Army Corps 1955;101:33-8.

6 Owen Smith MS. A computerised data retrieval system for the wounds of war: the Northern Ireland casualties.J R Army Med Corps 1981;127:31-54.

Mellor SG, Cooper GJ. Analysis of 828 servicemen killed or injured by explosion in Northern Ireland 1970-84: the hostile action casualty system. Br J Surg 1989;76:1006-10.

8 Gofrit ON, Leibovici D, Shapira SC, Shemer J, Stein M, Michaelson M. The trimodal death distribution of trauma victims: military experience from the Lebanon war. Mil Med 1997;162:24-6.

9 Butkovic-Soldo S, Brkic K, Puntaric D, Petrovicki Z. Medical corps support to a brigade action during an offensive action including river crossing. Mil Med 1995;160:408-11.

10 Melsom MA, Farrar MD, Volkers RC. Battle casualties. Ann R Coll Surg Engl 1975;56:287-303.

11 Bellamy RF. The medical effects of conventional weapons. World J Surg 1992;16:888-92.

12 Coupland RM. Epidemiological approach to the surgical management of the casualties of war. $B M J$ 1994:308:1693-7.

13 Mitchell TJ, Smith GM. Casualties and medical statistics of the Great War. London: Army Medical Services, His Majesty's Stationery Office, 1931:108.

14 Raszeja S, Chroscielewski E. Medicolegal reconstruction of the Katyn forest massacre. Forens Sci Int 1994;68:1-6.

15 Kovacevic S, Judas M, Marusic A. Civilian massacres in Banija:Kraljevcan and Pecki, 14-16 March 1991 [in Serbo-Croat]. Lijec Vjesn 1991;113:205-8.

16 Marcikic M, Marusic A. The civilian massacre in Dalj on 1 August 1991 [in Serbo-Croat]. Lijec Vjesn 1991;113:202-5.

17 Marcikic M, Krauz Z, Dmitrovic B, Mosunjac M, Marusic A. Civilian massacre near Podravsky Slatina, 3 September 1991 [in Serbo-Croat]. Lijec Vjesn 1991;113:208-10.

18 Broome G, Butler-Manuel A Budd J, Carter PG, Warlow TA. The Hungerford shooting incident. Injury 1988;19:313-7. 
19 Brinded BP, Taylor AJ. A mass killing in New Zealand. Aust N Z J Psychiatry 1995;29:316-20.

20 Beyersdorf SR, Nania JN, Luna GK. Community medical response to the Fairchild mass casualty event. Am J Surg 1996;171:467-70.

21 Curry JL. A disaster that could happen any where--the Palm Bay massacre. J Emerg Nurs 1990;16:42-8A.

22 Early E. Darnall Army Community Hospital's response to the Killeen massacre. J Emerg Nurs 1992;18:316-8.

23 Eckert WG. The St Valentine's Day massacre. Am J Forens Med Pathol 1980;1:67-70.

24 Meloy JR. Predatory violence during mass murder. J Forens $\mathrm{Sci}$ 1997;42:326-9.

25 Reay DT, Haglund WD, Bonnell HJ. Wah Mee massacre: the murder of 13 Chinese adults in a Seattle gambling club. Am J Forens Med Pathol 1986;7:330-6.

26 Coupland RM. Classification and management of war wounds. In: Johnson CD, Taylor I, eds. Recent advances in surgery. No 17. London: Churchill Livingstone, 1994:121-34.

27 Sellier KG, Kneubuehl BP. Wound ballistics. Amsterdam: Elsevier, 1994.
28 Kneubuehl BP. Small calibre weapon systems. In: Expert meeting on certain weapon systems and on implementation mechanisms in international law. Geneva: International Committee of the Red Cross, 1994:26-39.

29 Grossman D. On killing: the psychological cost of learning to kill in war and society. Boston: Little, Brown, 1995.

30 Anonymous. Nonlethal weapons: emerging requirements for security strategy. Washington, DC: Institute for Foreign Policy Analysis, 1996.

31 Arkin WM. Acoustic anti-personnel weapons: an inhumane future? Medicine, Conflict and Survival 1997;14:314-26.

32 Coupland RM. "Non-lethal" weapons: precipitating a new arms race. $B M J$ 1997;315:72.

33 Dando M. A new form of warfare: the rise of non-lethal weapons. London: Brassey's, 1996.

34 Lewer N, Schofield S. Non-lethal weapons: a fatal attraction? London: Zed Books, 1997.

35 Pengelly R. Wanted: a watch on non-lethal weapons. Int Defence Rev 1994;27:1.

36 Spinney L. A fate worse than death. New Scientist 1997 Oct 18:26-7. (Accepted 7 April 1999)

\title{
Effect of type and transfer of conventional weapons on civilian injuries: retrospective analysis of prospective data from Red Cross hospitals
}

\author{
Robin M Coupland, Hans O Samnegaard
}

\begin{abstract}
Editorial by Smith
Unit of the Chief Medical Officer, International

Committee of the Red Cross,

19 avenue de la Paix, 1202 Geneva Switzerland

Robin M Coupland

surgeon

Hans O

Samnegaard

surgeon

Correspondence to: Mr Coupland rcoupland@icrc.org
\end{abstract}

BMJ 1999;319:410-2

\begin{abstract}
Objective To examine the link between different weapons used in modern wars and their potential to injury civilians.

Design Retrospective analysis of prospectively collected data about hospital admissions.

Setting Hospitals of the International Committee of the Red Cross.

Subjects 18877 people wounded by bullets, fragmentation munitions, or mines. Of these, 2012 had been admitted to the hospital in Kabul within six hours of injury.

Main outcome measures Age and sex of wounded people according to cause of injury and whether they were civilians (women and girls, boys under 16 years old, or men of 50 or more).

Results $18.7 \%$ of those injured by bullets, $34.1 \%$ of those injured by fragments, and $30.8 \%$ of those injured by mines were civilians. Of those admitted to the Red Cross hospital in Kabul within six hours of injury, $39.1 \%$ of those injured by bullets, $60.6 \%$ of those injured by fragments, and $55.0 \%$ of those injured by mines were civilians.

Conclusions The proportion of civilians injured differs between weapon systems. The higher proportion injured by fragments and mines is explicable in terms of the military efficiency of weapons, the distance between user and victim, and the effect that the kind of weapon has on the psychology of the user.
\end{abstract}

\section{Introduction}

The use of weapons against people or targets containing people inevitably has a direct impact on the health of those people. ${ }^{12}$ This impact is related to factors dependent on the design of weapons and on their use. The nature of injury is closely related to the design of the weapon; wounds from bullets, fragments, and buried antipersonnel mines are distinguishable ${ }^{3-6}$ Factors dependent on the user, such as discipline and desire to avoid or injure civilians, determine the number and kind of people injured ${ }^{5-10}$ and may, in the case of bullets, determine which part of the body is injured. This century has seen an increased proportion of civilians injured during war. ${ }^{10}$ This is usually ascribed to military weapons passing into the hands of those with no respect for the civilian population or the Fourth Geneva Convention, which protects civilians. In parallel, there has been an extraordinary development of the military efficiency of weapons. ${ }^{11}$ This generates a provocative question: to what extent is the weapon development this century linked to the increased proportion of civilians injured? This poses a further question: does increased ease with which a weapon can be used to achieve military objectives (military efficiency) increase the potential for civilian casualties? ${ }^{\text {?2 }}$

The hallmarks of countries where most modern wars are fought are poverty, destroyed social and economic infrastructure, and availability of a variety of weapons. ${ }^{1}$ Disciplined armies train their soldiers in the laws of war, which include respect for the civilian population; by contrast, modern wars tend to be fought by forces that are poorly trained and may even target civilians. Another feature of these modern wars is that competent medical facilities are few or non-existent. Care of those wounded during these conflicts has fallen to international aid agencies. One of the few sources of data about casualties in these wars is the hospitals run by the International Committee of the Red Cross. We examined all the data held by the Red Cross on wound injuries treated in its hospitals from January 1991 to July 1998 to explore these two questions. We also examined data from the Kabul hospital during a period when the city of Kabul was under siege.

\section{Patients and methods}

\section{Database}

The wound database of the International Committee of the Red Cross was installed in January 1991 and originates from a system of data collection originally 